\title{
Virulence and SSR Diversity of Brown Planthopper (Nilaparvata lugens) Adapted on Differential Rice Host Varieties
}

\author{
Chaerani ${ }^{*}$, Ahmad Dadang, Sutrisno, Bahagiawati Amir Husin, Muhamad Yunus \\ Indonesian Center for Agricultural Biotechnology and Genetic Resources Research and Development, Bogor, Indonesia
}

ARTICLE INFO

Article history:

Received December 28, 2020

Received in revised form September 1, 2021

Accepted September 15, 2021

\section{KEYWORDS:}

biotype,

brown planthopper,

DNA marker,

virulence

\begin{abstract}
Brown planthopper biotype 1, 2, 3 and a representative field population are required for resistance screening of promising rice lines in Indonesia, but the current biotype stocks has shown deviation in virulence patterns. The objectives of this study were to develop a set of brown planthopper populations with differential virulence and to investigate their genetic variability using SSR marker. Females originated from two field populations were selected on variety Mudgo (carries Bph1 gene) or ASD7 (bph2 gene) using honeydew excretion as the virulence parameter. Selection cycles resulted in population $T, M, A$, and $R$, which was raised and adapted on variety TN1 (carries no Bph gene), Mudgo, ASD7, and Rathu Heenathi (Bph3, Bph17), respectively. Population $R$ was the most virulent as expected and can be used to represent a field population, but the remaining populations still showed high virulence level. AMOVA and PCoA results based on analysis with 38 SSR primer pairs revealed partial genetic separation among populations, with population $R$ was the most genetically distant from the remaining populations. The desired virulence character of the remaining populations is expected could be achieved after further selection and prolonged adaptation on their respective hosts.
\end{abstract}

\section{Introduction}

Rice cultivation in lowland and upland areas of Indonesia is annually suffered from brown planthopper (BPH, Nilaparvata lugens Stål [Hemiptera: Delphacidae]) infestation (Baehaki and Mejaya 2014). Both nymphs and adults aggregate on the basal portion of rice plants sucking the phloem sap (Claridge et al. 1985). Under high BPH infestation, plants can suffer from rapid wilting and complete drying, which are observed as hopper-burn in the rice field (Pathak and Khan 1994). Secondary damage to plants occurs when the insect transmit viral diseases (Cheng et al. 2013).

Variation in virulence of BPH population, or commonly termed as biotype, has been the major obstacle in obtaining durable resistant rice varieties to this pest (Baehaki and Mejaya 2014). BPH biotypes are determined based on resistance reactions of four differential rice varieties carrying $B p h$ genes: the variety TN1 with no known Bph genes is susceptible to all BPH biotypes, Mudgo (Bph1) is susceptible to biotype 2 and 4, whereas ASD7 (bph2) is susceptible

* Corresponding Author

E-mail Address: chaeran1@yahoo.com to biotype 3 and 4 (Brar et al. 2009). Among BPH biotypes, differences in morphometric and mating barrier are absent (Claridge et al. 1984).

BPH biotype 1 to 3 and a representative field population are used as resistance screening agents of promising rice lines in Indonesia (Baehaki 2012). Rice lines possess resistance to one of these populations can be released as new varieties (Sasmita et al. 2019). However, BPH populations used in screening trials can be problematic. Firstly, contamination of biotype stocks or deviations in the virulence patterns on samples of biotypes can occur (Manzila et al. 2002; Baehaki and Munawar 2008). Secondly, BPH field population must be replaced every five generations of rearing (Baehaki 2012). Consequently, a new field population must be reestablished which requires extra costs and time. A comparable virulent population which can defeat multiple Bph gene(s) and maintained permanently on its respective host can be a good substitute for a field population.

Selection of BPH virulence or purification of contaminated biotypes is possible due to the high adaptability of the insect on rice host. Pathak and Heinrichs (1982) successfully developed biotypes 2 and 3 after selecting individuals from a field 
population that previously could not defeat the variety Mudgo and ASD7. Later, Khan and Saxena (1990) and also Manzila et al. (2002) purified biotype 1 population from contaminated stocks.

Host evolution adaptability and genetic variation of insect population can be detected via DNA marker analysis (Wenger and Michel 2013). RAPD marker is the first molecular marker type used in the genetic studies of BPH biotypes but failed (Shufran and Whalon 1995) or partially succeeded (Bahagiawati and Rijzaani 2005) in distinguishing biotype populations. For population genetic studies SSR marker is considered more reliable than RAPD due to its locus specificity and high reproducibility (Jing et al. 2012a). Hundreds of SSR markers have been mined from BPH expressed sequence tags (EST) database (Liu and Hou 2009; Sun et al. 2011; Jing et al. 2012a) and from isolation of BPH genomic DNA (Jing et al. 2012b; Jairin et al. 2013). The application of a set of 61 EST-SSR loci has successfully differentiated four BPH biotypes (Jing et al. 2012a). The objectives of this paper were to artificially develop four $\mathrm{BPH}$ populations with differential virulence and to differentiate the developed population genetically by application of SSR markers.

\section{Materials and Methods}

\subsection{Development of BPH Population}

Three field populations (S1, JWDL, and X1) raised on their respective rice cultivars (Manohara, Ciherang and Ciliwung, respectively) for $\geq 20$ generations (Chaerani et al. 2016) were used as the source of insect selection. Population S1 and JWDL was characterized to have the virulence pattern of biotype 2 and 4, respectively, whereas X1 was a highly virulent population on 10 differential varieties (Chaerani et al. 2016). Nymphs of $4^{\text {th }}$ to $5^{\text {th }}$ instar were individually raised until molting on seedlings of their respective rice cultivar planted in plastic cups. Seedlings were confined with transparent plastic cylinders with its top covered with nylon cloth. Females of 24 to 48 hours after molting were selected and individually transferred to $2.0-\mathrm{ml}$ microtubes containing damp filter paper and capped with perforated lids. After left for 2 hours, they were individually caged in $50 \mathrm{~mm} \times$ $41 \mathrm{~mm}$-parafilm sacs (Pathak et al. 1982) attached to the stems of $4-w . o$. potted Mudgo plants. One to three parafilm sacs were attached on different position of each rice stem. After 48 hours, females were carefully removed from the sacs and returned to the microtubes. Sacs containing honeydew were weighed. Honeydew weight was known by subtracting the weight of filled sacs with the mean weight of empty sacs. Females excreting $<10 \mathrm{mg}$ and $>20 \mathrm{mg}$ of honeydew were categorized as nonvirulent and virulent, respectively (Tanaka 1999). Non-virulent females were subsequently raised on TN1 (carries no Bph gene) plants, whereas the virulent ones on Mudgo (Bph1) plants. Females excreting 10 to $20 \mathrm{mg}$ honeydew were discarded. After one generation of rearing, females from both cultivars were selected on ASD7 (bph2) at the second selection cycle. Non-virulent females were raised on TN1, whereas virulent females were raised on ASD7 or Rathu Heenathi (Bph3, Bph17) plants. At the $3^{\text {rd }}$ selection cycles, females were tested on Mudgo or ASD7. The selected individuals were subsequently raised on TN1, Mudgo, ASD7, or Rathu Heenathi according to the virulence group. Progenies adapted on these hosts were designated as population $\mathrm{T}$, $\mathrm{M}, \mathrm{A}$, and $\mathrm{R}$, respectively. The complete virulence selection steps were depicted in Figure 1. In each step of selection and rearing cycle, populations were kept in insect proof cage.

\subsection{Virulence Test}

The virulence patterns of BPH population were checked by means of the standard seed box screening technique (Baehaki 2012) and a slight modification of host preference test from Jing et al. (2014). When used in the virulence tests, population $\mathrm{T}$ and A were at the $2^{\text {nd }}$ and $3^{\text {rd }}$ generation, respectively, whereas population $\mathrm{M}$ and $\mathrm{R}$ were at $4^{\text {th }}$ generation after the final selection cycle.

For standard seed box screening technique (SSST), host plants bearing the $2^{\text {nd }}$ and $3^{\text {rd }}$ instars were tapped on the seed box planted with TN1, Mudgo, ASD7 and Rathu Heenathi seedlings (20 seedlings per cultivar per row). Plant damages were scored when $\geq 90 \%$ TN1 seedlings were dead using individual plant score following the criteria of Sun et al. (2005) and Kumari et al. (2010), i.e. 0: none of the leaves shrank and the plant was healthy, 1: one leaf was yellowing, 3: partial yellowing of the first and second leaf and one leaf shrank, 5: pronounced yellowing of half of the plant and one to two leaves shrank or one leaf shriveled, 7: wilting of more than half of the plant or three to four leaves shriveled and 
$1^{\text {st }}$ select

cycle

$2^{\text {nd }}$ select

cycle

${ }^{\text {rd }}$ select

cycle

th select

cycle

Virulence test of 285 females derived from three field populations on Mudgo (Bph1)

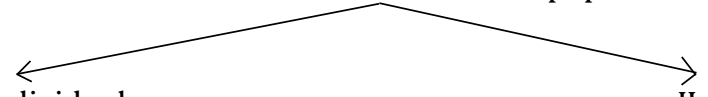

I. 146 (51\%) avirulent individuals<smiles>C1CCCC1</smiles>

Raised on TN1 (no Bph gene) for one generation

163 females tested for virulence on ASD7 ( $b p h 2)$

I.1. $1 0 \longdiv { ( 6 6 \% ) }$ avirulent individuals<smiles>C=CC</smiles>

Raised on TN1 for one generation<smiles>C1CC1</smiles>

31 females tested for virulence on Mudgo<smiles>C1CC1</smiles>

24 (77\%) avirulent individuals selected<smiles>C=[V]</smiles>

Raised on TN1 for one generation<smiles>C1CCC1</smiles>

63 females tested for virulence on Mudgo

53 avirulent (84\%)

females selected<smiles>C=[V]</smiles>

Raised on TN1 for generation

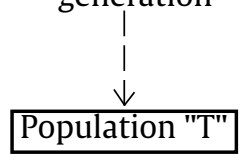

I.2. 35 (22\%) virulent individuals

Raised on ASD7 for one generation

53 females tested for virulence on ASD7<smiles>C=CC</smiles>

25 (47\%) virulent individuals selected

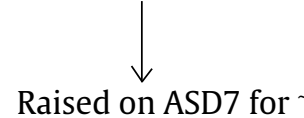
generation

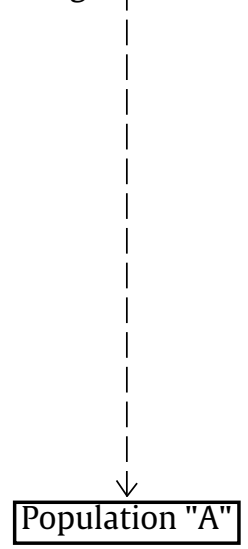

II. 92 (32\%) virulent individuals

Raised on Mudgo (Bph1) for one generation

148 females tested for virulence on ASD7 (bph2)

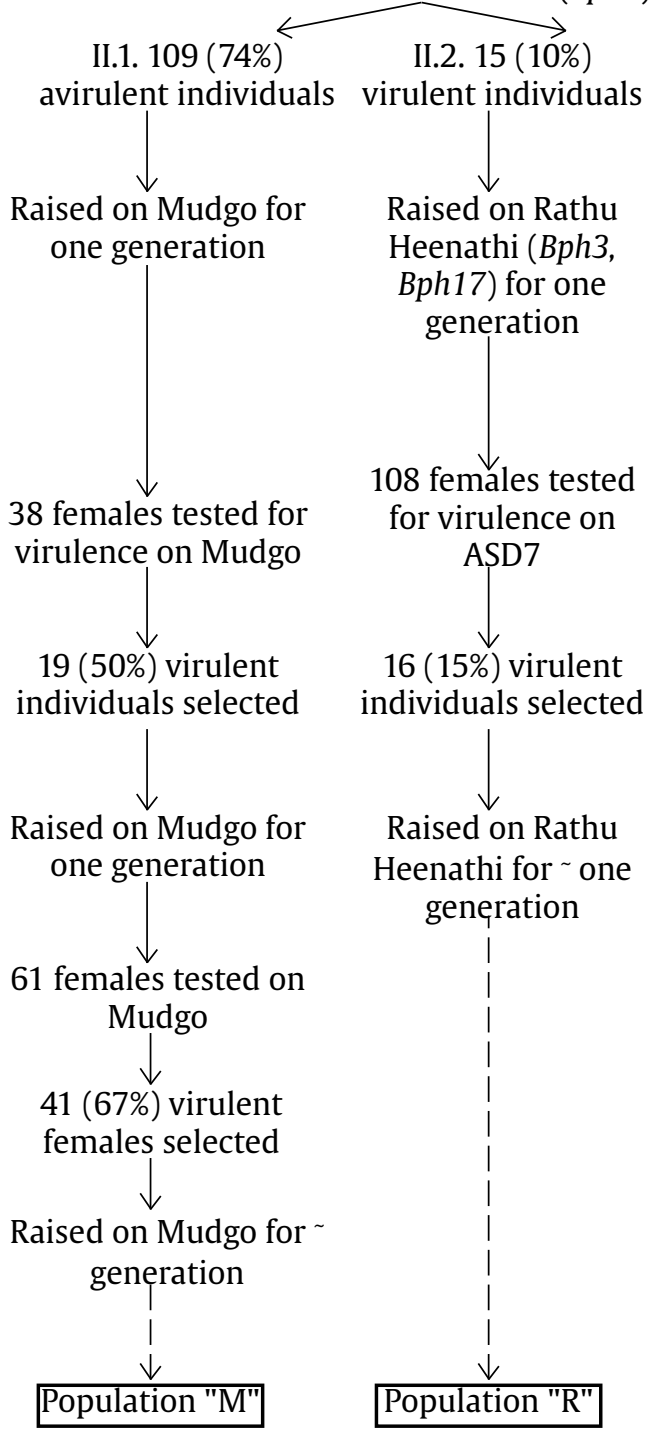

Figure 1. Scheme used for development of four rice brown planthopper (Nilaparvata lugens Stål) populations with differential virulence on differential varieties 
the plant was still alive, and 9: whole plant dead. The SSST was done in three replications, where one box was considered as a replication. Varietal response was used for assignment of BPH biotype. BPH was categorized as biotype 1 if Mudgo, ASD7 and Rathu Heenathi were resistant (damage score $<5)$; biotype 2 if ASD7 and Rathu Heenathi were resistant; biotype 3 if Mudgo and Rathu Heenathi were resistant; and biotype 4 if Rathu Heenathi was resistant Brar et al. (2009).

Host preference test was done by tapping host plants carrying $2^{\text {nd }}$ and $3^{\text {rd }}$ nymphs to the center of 10-liter pots planted with 45-d.o. differential varieties TN1, Mudgo, ASD7 and Rathu Heenathi. Plants were immediately caged with plastic cylinders after infestation. Nymphs settled on each rice cultivar were recorded at 4, 24, 30, 54, and 72 hours after infestation (h.a.i.). The test method was done in three replications (pots).

\subsection{SSR Analysis}

Genomic DNAs were extracted individually from the head and thorax of female $(n=10)$ of each population using SDS protocol (Latief et al. 2012). DNA concentrations were measured by a spectrophotometer and adjusted to $10 \mathrm{ng} / \mu \mathrm{l}$. A total of 132 SSR primer pairs from Jing et al. (2012a), Jairin et al. (2013), Liu and Hou (2009), and Sun et al. (2011) were tested for polymorphism on four DNA pools of five individuals. PCR amplification was conducted in $10-\mu$ reaction mixture containing $1 \times$ PCR buffer, $0.2 \mathrm{~mm}$ of each dNTP, $0.3 \mathrm{~mm}$ of each primer, $1 \mathrm{U}$ of Taq DNA polymerase (Vivantis), and $20 \mathrm{ng}$ of DNA template. PCR amplification were performed on a Bio-Rad thermal cycler using the following cycling profile: a 5 -min denaturation step at $94^{\circ} \mathrm{C}$ was followed by 39 cycles of $30 \mathrm{~s}$ denaturation at $94^{\circ} \mathrm{C}$, $30 \mathrm{~s}$ annealing at $55^{\circ} \mathrm{C}$, and $60 \mathrm{~s}$ extension at $72^{\circ} \mathrm{C}$. The PCR cycle was terminated with a 7-min final extension at $72^{\circ} \mathrm{C}$. PCR products were size separated on $4 \%$ agarose gels in $0.5 \times$ TBE for 2 to $2.5 \mathrm{~h}$ at 150 $\mathrm{V}$ electric current. Allele sizes were determined by comparing it with a 100-bp DNA ladder (Vivantis) which was run together with samples. Gels were stained with ethidium bromide $(5 \mu \mathrm{g} / \mathrm{l})$ and visualized under UV light (Chemidoc XRS Bio-Rad). Primers yielding polymorphic bands were used for amplification of 10 females per population.

\subsection{Data Analysis}

DNA bands were scored bi-allelic based on the allele size as presence (' 1 ') and absence (' 0 ') for the respective allele size. The allele number produced by each marker and the informativeness of a marker as measured by polymorphic information content (PIC) value were calculated using PowerMarker 3.25 (Liu and Muse 2005). Calculation of population genetic parameters (allele number, heterozygosity, fixation index, and Shannon's index), hierarchical analysis of molecular variance (AMOVA), and principle coordinate analysis (PCoA) of BPH populations were performed using GenAlex 6.5 (Peakall and Smouse 2012).

Markers showing PIC value $<0.5$ are categorized as not informative (Botstein et al. 1980). Excess heterozygosity is present in a population when its value of fixation index (F) is negative (Xu et al. 2016; Yang et al. 2016). When the overall inbreeding coefficient (Fst) obtained from AMOVA result is greater than zero, a genetic differentiation among populations is declared to present (Luo et al. 2019).

\section{Results}

\subsection{Development of BPH Populations}

Three selection cycles were performed to obtain virulent BPH females on ASD7, whereas four selection cycles were done to identify Mudgoavirulent or Mudgo-virulent individuals (Figure 1). Initial selection of 285 females on Mudgo resulted in Mudgo-avirulent (group I) and Mudgo-virulent (group II) individuals, which were subsequenlty raised on TN1 and Mudgo, respectively. Progenies from each group underwent virulence selection on ASD7 at the $2^{\text {nd }}$ cycle and resulted in four subgroups, i.e. I.1, I.2, II.1, and II.2. Progenies of subgroup I.1 and II.1 which were derived from one generation rearing on TN1 and Mudgo, respectively, were selected at the $3^{\text {rd }}$ cycle on Mudgo. The resulting Mudgo-avirulent females from subgroup I.1 and Mudgo-virulent females from subgroup II.1 were raised on TN1 and Mudgo, respectively, and continued to be selected on the $4^{\text {th }}$ cycle to result in population $T$ consisting of Mudgo-avirulent individuals and population $\mathrm{M}$ consisting of Mudgo-virulent individuals. Progenies of subgroup I.2 and subgroup II.2 were both selected for ASD7-virulent individuals. Virulent individuals were raised on ASD7 and Rathu Heenathi, and the progenies were labeled as population $A$ and $R$, respectively. Examples of honeydew excretion in each class of virulence are depicted in Figure 2.

Generally, virulence selection cycles successfully increased the number of virulent females by approximately 20\%, except for ASD7-virulent females raised as population $R$. In contrast, the proportion of ASD7-virulent females in population $\mathrm{R}$ increased by only $5 \%$ at the $3^{\text {rd }}$ selection cycle (Figure 1). 

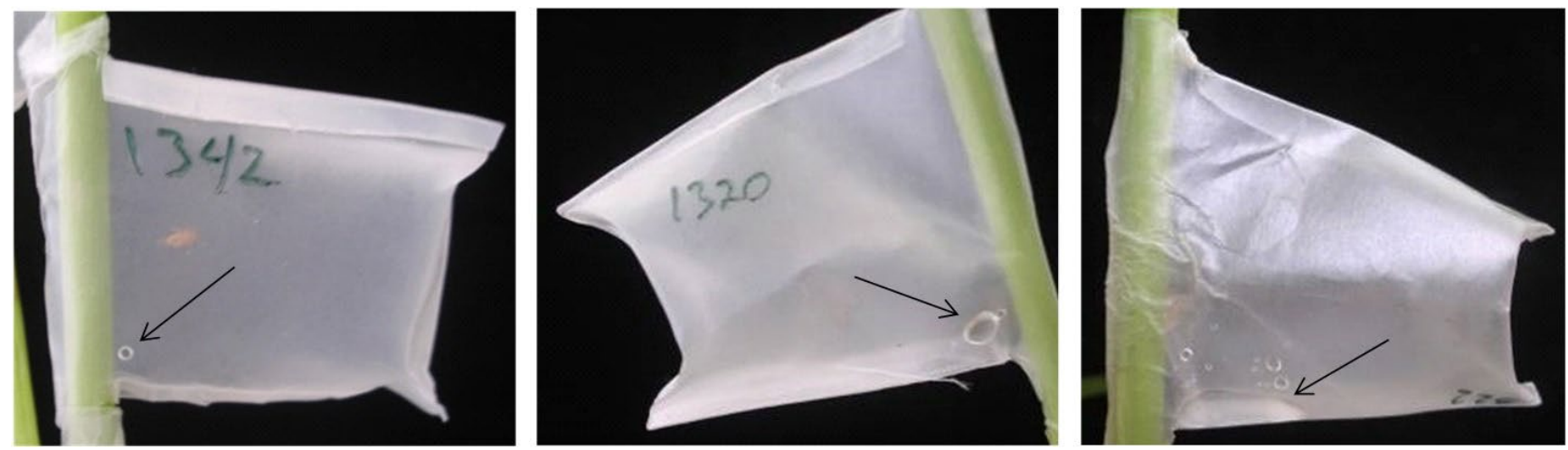

Figure 2. Honeydew excretion of a non-virulent (left panel), an intermediate virulent (center panel), and a virulent female (right panel) of rice brown planthopper (Nilaparvata lugens Stål) fed on differential varieties Mudgo (Bph1) or ASD7 (bph2) for $48 \mathrm{~h}$. Non-virulent females excrete $<10 \mathrm{mg}$ honeydew, whereas virulent females excrete $>20 \mathrm{mg}$ honeydew

\subsection{Virulence Phenotype}

Plant damage on the SSST method was evaluated on day 3 to 4 after nymphal infestation when $\geq 90 \%$ of TN1 seedlings were dead. The SSST revealed that only population $\mathrm{R}$ had the expected virulence character, i.e. it can defeat all four varieties tested. Population $\mathrm{T}$ and $\mathrm{M}$ displayed biotype 4 virulence character although they were selected and developed as biotype 1 and 2, respectively (Table 1). Population A, which was selected and developed as biotype 4 , was comparably highly virulent with population $\mathrm{R}$.

Host preference test showed that the majority of population T nymphs settled on Mudgo variety, but starting at 54 h.a.i. more nymphs also chose the variety TN1 (Figure 3). Both ASD7 and Rathu Heenathi were equally less preferred by population $\mathrm{T}$ at all points of observation. TN1, Mudgo and ASD7 were chosen by the nymphs of population $\mathrm{M}$, but at the end of evaluation time more nymphs chose Rathu Heenathi. The majority of nymphs from population A settled on Mudgo and a lower percentage of nymphs equally preferred TN1 and ASD7. The variety ASD7 was preferred by the nymphs of population R, whereas TN1, Mudgo and Rathu Heenathi were equally less preferred. Based on the nymphal host preference, population $\mathrm{T}$ and $\mathrm{A}$ may have the biotype 2 and 3 virulence pattern, respectively, whereas population $M$ and $\mathrm{R}$ were more virulent than biotype 4 . Both SSST and host preference test confirmed the virulence characteristics of population $\mathrm{R}$.

\subsection{SSR Analysis}

\subsubsection{Marker Polymorphism}

PCR of DNA pools from 10 individuals of each BPH population using 132 primers resulted in $73 \%$ success rate of DNA amplification, but only 42 (32\%) primers yielded polymorphic loci (Table 2 ). Of the polymorphic loci, 38 primers which yielded clear and scorable bands were subsequently used in genetic analysis of 10 females per population. Examples of DNA amplification by SSR markers are given in Figure 4.

The allele number produced by SSR markers ranged from two to eight with an average of four alleles (Table 3 ). Fifteen markers were categorized as informative (PIC >0.5). The highest and the lowest PIC value were obtained from the marker NLES34 (0.75) and BM64 (0.13), respectively.

\subsubsection{Population Genetic Diversity}

There were high and similar rate of marker polymorphism among populations, with the highest and lowest percentage was in population $\mathrm{T}$ (95\%) and A (87\%), respectively (Table 4$)$. Values of the genetic parameter ( $\mathrm{Na}, \mathrm{Ne}, \mathrm{I}, \mathrm{Ho}, \mathrm{He}$, and uHe) were similar among the four populations (Table 4). The number of private alleles in each population was less than 1 , indicating the presence of close genetic relationship among populations. Excess heterozygosity was absent in each population as indicated by positive values of fixation index.

A hierarchical AMOVA indicated that most of the genetic variation was resided within population 
Table 1. Seedling damage scores of four rice differential varieties after infested with nymphs of four artificial selected brown planthopper populations using the standard seed box screening technique

\begin{tabular}{lrrrc}
\hline \multirow{2}{*}{ Variety (Bph resistance gene) } & \multicolumn{4}{c}{ Brown planthopper population $^{\mathrm{a}}$} \\
\cline { 2 - 4 } & $\mathrm{T}$ & $\mathrm{M}$ & $\mathrm{A}$ & $\mathrm{R}$ \\
\hline TN1 (carries no Bph gene) & $8.8 \pm 1.1(\mathrm{~S})$ & $9.0 \pm 0.3(\mathrm{HS})$ & $8.8 \pm 0.6(\mathrm{HS})$ & $8.8 \pm 0.7(\mathrm{HS})$ \\
Mudgo (Bph1) & $7.6 \pm 4.7(\mathrm{MS})$ & $5.3 \pm 4.0(\mathrm{MS})$ & $8.2 \pm 1.1(\mathrm{HS})$ & $8.1 \pm 1.8(\mathrm{HS})$ \\
ASD7 (bph2) & $7.8 \pm 4.7(\mathrm{MS})$ & $5.9 \pm 3.9(\mathrm{MS})$ & $8.3 \pm 1.0(\mathrm{HS})$ & $8.0 \pm 1.4(\mathrm{HS})$ \\
Rathu Heenathi $($ Bph3, Bph17) & $1.8 \pm 3.4(\mathrm{R})$ & $3.3 \pm 4.0(\mathrm{MR})$ & $6.7 \pm 2.8(\mathrm{MS})$ & $5.2 \pm 3.6 \mathrm{MS})$ \\
\hline
\end{tabular}

apopulation T, M, A, and R were the results of virulence selection cycles of three field populations on Mudgo (Bph1) and ASD7 (bph2), and maintained on TN1 (no Bph gene), Mudgo, ASD7, and Rathu Heenathi (Bph3, Bph17), respectively. Figures are means of damage scores of 20 seedlings individually rated as 0 : none of the leaves shrank and the plant was healthy, 1: one leaf was yellowing, 3: partial yellowing of the first and second leaf or one leaf shrank, 5: pronounced yellowing of half of the plant and one to two leaves shrank or one leaf shriveled, 7: wilting of more than half of the plant or three to four leaves shriveled and the plant was still alive, and 9: whole plant dead. Resistance was categorized as highly resistant (HR), resistant (R), moderately resistant (MR), moderately susceptible (MS), susceptible (S) and highly susceptible (HS) when the damage score was $0-1,>1-3,>3-5,>5-7,>7-8$, and $>8-9$, respectively. BPH population was designated as biotype 1 if TN- 1 was susceptible (mean damage score $<5$ ), biotype 2 if TN- 1 and Mudgo were susceptible, biotype 3 if TN-1 and ASD7 were susceptible; and biotype 4 if TN1, Mudgo and ASD7 were susceptible
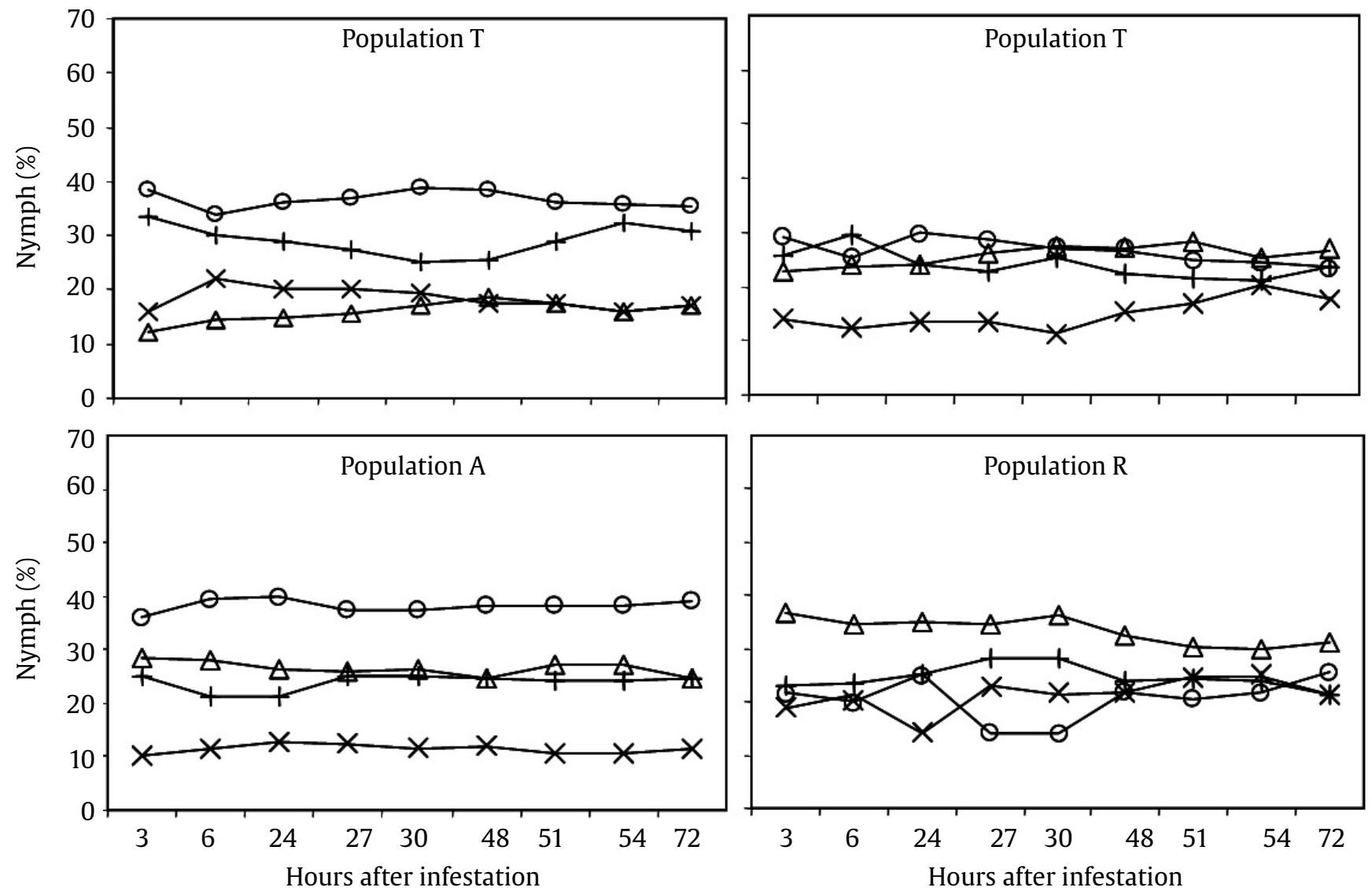

—TN1 (no Bph gene) $\multimap$ Mudgo (Bph1) $\triangle$ ASD7 (Bph7) $\rightarrow$ Rathu Heenathi (Bph3, Bph17)

Figure 3. Percentage of brown planthopper (Nilaparvata lugens Stål) nymphs settled on four rice differential varieties obtained from a triplicate time-course experiment. See Table 1 for explanation of each population 
Table 2. PCR amplification results of 132 SSR primers on DNA pools of four rice brown planthopper (Nilaparvata lugens Stål) populations maintained on differential varieties

\begin{tabular}{lc}
\hline Amplification category & Number of primer (percentage) \\
\hline Polymorphic & $42(31.8 \%)$ \\
Monomorphic & $42(31.8 \%)$ \\
Inconsistent & $12(9.1 \%)$ \\
Fail & $36(27.3 \%)$ \\
\hline Total primer & 132 \\
\hline
\end{tabular}

with an equal variation among and within individuals (46\% and 43\%, respectively; Table 5). The value of inbreeding coefficient (Fst), which provides a measure of the genetic differentiation structure, was greater than zero (Table 6), indicating the presence of genetic differentiation among population. The highest and the least genetic differentiation was between pair of population $M$ and $\mathrm{R}(\mathrm{Fst}=0.140)$ and between population $\mathrm{M}$ and $\mathrm{T}$ $($ Fst $=0.059)$, respectively $($ Table 6$)$.

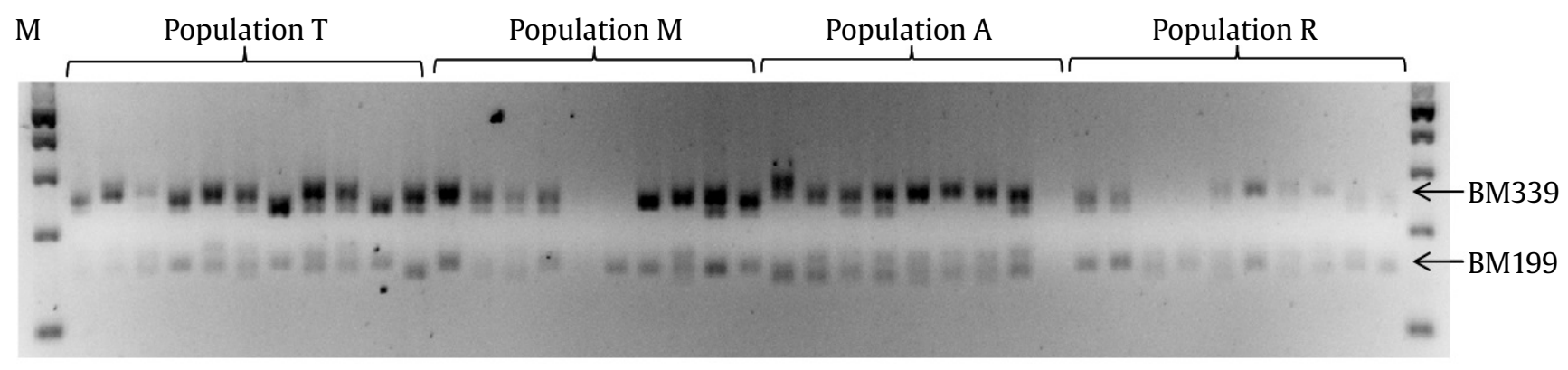

Figure 4. Multiloaded PCR products of genomic DNA of four rice brown planthopper (Nilaparvata lugens Stål) populations amplified by the SSR primer BM199 and BM339. M = 100 bp ladder. See Table 1 for explanation of each population

Table 3. Performance of 38 polymorphic SSR markers used in genetic analysis of four rice brown planthopper (Nilaparvata lugens Stål) populations maintained on differential varieties

\begin{tabular}{|c|c|c|c|c|c|c|c|}
\hline Marker & $\mathrm{Na}^{\mathrm{a}}$ & $\begin{array}{l}\text { Allele size } \\
\text { range (bp) }\end{array}$ & $\mathrm{PIC}^{\mathrm{b}}$ & Marker & $\mathrm{Na}^{\mathrm{a}}$ & $\begin{array}{l}\text { Allele size } \\
\text { range (bp) }\end{array}$ & $\mathrm{PIC}^{\mathrm{b}}$ \\
\hline NLES34c & 5 & $140-210$ & 0.75 & NLES49" & 4 & $300-350$ & 0.43 \\
\hline BM1262 & 6 & $157-216$ & 0.74 & BM68 & 3 & $285-325$ & 0.43 \\
\hline NLES11 $^{\mathrm{c}}$ & 5 & $222-315$ & 0.71 & BM1277 & 2 & $175-185$ & 0.42 \\
\hline NLGS1126c & 7 & $157-265$ & 0.70 & BM246c & 4 & $290-350$ & 0.42 \\
\hline BM265 & 4 & $177-200$ & 0.68 & DB839391 & 3 & 173-195 & 0.41 \\
\hline NLES22 & 5 & $172-201$ & 0.68 & ВPH06 & 4 & $152-200$ & 0.41 \\
\hline BM194 & 5 & $159-180$ & 0.67 & BM499' & 3 & 136-162 & 0.41 \\
\hline NLES2d & 7 & 116-165 & 0.67 & BM375" & 6 & $190-259$ & 0.40 \\
\hline NLGS231 ${ }^{\mathrm{c}}$ & 8 & $253-446$ & 0.66 & BM379 & 3 & $234-266$ & 0.37 \\
\hline BM302 & 4 & $205-244$ & 0.63 & BM410' & 4 & $190-300$ & 0.36 \\
\hline NLES24 & 4 & $195-234$ & 0.61 & BM $440^{\circ}$ & 4 & $260-367$ & 0.35 \\
\hline BM395 & 4 & 146-172 & 0.60 & DB845048 & 2 & 109-115 & 0.35 \\
\hline NLES33 $^{c}$ & 8 & $150-266$ & 0.59 & ВM339 & 2 & $230-250$ & 0.34 \\
\hline BM25 & 5 & $277-330$ & 0.57 & BM432 & 4 & $275-330$ & 0.23 \\
\hline NLES8 & 4 & $100-140$ & 0.57 & BM298 & 2 & $186-230$ & 0.19 \\
\hline NLES15c & 3 & $190-205$ & 0.49 & BM1283 & 2 & $230-240$ & 0.17 \\
\hline NLES35 & 5 & $146-180$ & 0.48 & BM1295 & 3 & $135-145$ & 0.16 \\
\hline BM76c & 5 & $230-310$ & 0.48 & BM140' & 3 & $244-258$ & 0.16 \\
\hline \multirow[t]{2}{*}{ BM435 } & 3 & 120-132 & 0.43 & BM64c & 3 & 219-271 & 0.13 \\
\hline & & & Mean & & 4 & & 0.47 \\
\hline
\end{tabular}

${ }^{\mathrm{a} N a:}$ number of allele

bPIC: polymorphic information content

'Marker that detects private allele (allele unique to a single population) 
Table 4. Genetic diversity of four rice brown planthopper (Nilaparvata lugens Stål) populations based on 38 SSR markers

\begin{tabular}{llllllllll}
\hline Population $^{\mathrm{a}}$ & $\mathrm{P}(\%)$ & $\mathrm{Na}$ & $\mathrm{Ne}$ & $\mathrm{I}$ & $\mathrm{Ho}$ & $\mathrm{He}$ & $\mathrm{uHe}$ & $\mathrm{F}$ & $\mathrm{Pa}$ \\
\hline $\mathrm{T}$ & 94.7 & 2.7 & 1.8 & 0.710 & 0.277 & 0.412 & 0.439 & 0.290 & 0.2 \\
$\mathrm{M}$ & 89.5 & 2.7 & 2.0 & 0.720 & 0.307 & 0.425 & 0.457 & 0.279 & 0.2 \\
$\mathrm{~A}$ & 86.8 & 3.0 & 2.1 & 0.771 & 0.303 & 0.432 & 0.461 & 0.300 & 0.3 \\
$\mathrm{R}$ & 89.5 & 2.7 & 2.0 & 0.720 & 0.354 & 0.418 & 0.447 & 0.162 & 0.2 \\
\hline Mean & 90.1 & 2.8 & 2.0 & 0.729 & 0.310 & 0.422 & 0.451 & 0.258 & - \\
\hline
\end{tabular}

a See Table 1 for explanation of each population. P: polymorphic locus, Na: number of different allele, Ne: number of effective allele, I: Shannon's index, He: expected heterozygosity, uHe: unbiased heterozygosity, F: fixation index, and Pa: number of private allele (allele unique to a single population). Genetic parameter data were obtained from mean of 10 individuals

Table 5. Analysis of molecular variance (AMOVA) for 40 individuals of four rice brown planthopper (Nilaparvata lugens Stål) populations based on 38 SSR markers

\begin{tabular}{lcccc}
\hline $\begin{array}{l}\text { Source of } \\
\text { variation }\end{array}$ & d.f. & SS & $\begin{array}{c}\text { Estimates of } \\
\text { variance } \\
\text { components }\end{array}$ & $\begin{array}{c}\text { Molecular } \\
\text { variation } \\
(\%)\end{array}$ \\
\hline $\begin{array}{l}\text { Among } \\
\text { population }\end{array}$ & 3 & 123,763 & 1,260 & 11 \\
$\begin{array}{c}\text { Among } \\
\text { individuals }\end{array}$ & 36 & 577,700 & 5,474 & 46 \\
$\begin{array}{l}\text { Within } \\
\text { individuals }\end{array}$ & 40 & 204,000 & 5,100 & 43 \\
$\begin{array}{l}\text { Total } \\
\text { Inbreeding coefficient (Fst) }=0.107, \mathrm{P}=0.001\end{array}$ & 905,463 & 11,834 \\
\hline
\end{tabular}

Table 6. Pairwise population Fst values of four rice brown planthopper (Nilaparvata lugens Stål) populations

\begin{tabular}{lccc}
\hline Population $^{\mathrm{a}}$ & $\mathrm{T}$ & $\mathrm{M}$ & $\mathrm{A}$ \\
\hline $\mathrm{M}$ & 0.059 & $\ldots$ & $\ldots$ \\
$\mathrm{A}$ & 0.106 & 0.061 & $\ldots$ \\
$\mathrm{R}$ & 0.135 & 0.140 & 0.133 \\
\hline
\end{tabular}

aSee Table 1 for explanation of each population

Bi-plots of PCoA visualized the genetic relatedness among populations (Figure 5). Plot of axis 1 vs 2,1 vs 3 , and 2 vs 3 accounted for $44.2 \%$, $42.1 \%$, and $37.1 \%$ of the total genetic variation, respectively. Three clusters were observed which contained a mixture of individuals from two to three populations. Most individuals $(\geq 6)$ of population $\mathrm{T}, \mathrm{A}$ and $\mathrm{R}$ formed separate clusters, whereas individuals of population $M$ were clustered with individuals from population $\mathrm{T}$ and A. Population $\mathrm{R}$ was almost completely separated from the remaining populations, consistent with the observed high pairwise Fst values between this population with the other populations (Table 6).

\section{Discussion}

Four BPH populations have been developed by selecting individuals with desired virulence character on the variety Mudgo and ASD7 from three field populations. However, virulence tests by means of mass screening revealed only two biotype virulence patterns among these populations, whereas host preference test indicated the presence of three biotype groups. The results of host preference test may unreliable because of short evaluation time, i.e. $72 \mathrm{~h}$ after nymphal infestation, without considering the plant damage, and therefore prolonged observation may give different results. According to the SSST, population $\mathrm{T}$ and $\mathrm{M}$ displayed biotype 4 virulence pattern and population A showed highly virulent character instead of the desired biotype 1, 2 and 3 virulence pattern, respectively. Only population $R$ was highly virulent as expected after only three selection cycles.

Our results showed the complexity in developing BPH biotypes with lower virulence level from field population(s), even though one of the starting populations had the character of biotype 2 virulence. In contrast, Manzila et al. (2002) obtained biotype 1 after selection and 3 to 4 generation of adaptation on TN1 variety, but were unsuccessful in selecting biotype 2 and 3 individuals from contaminated biotype 1 stock. Therefore, the starting genetic material for virulence selection largely determines the success rate of biotype purification. According to Claridge and Hollander (1980), a BPH population is consisted of individuals with a range of virulence pattern of which proportion determined the virulence level of the population. Additionally, a field population is potentially consisted of various genotypes with 
Principal coordinates (1 vs 2)

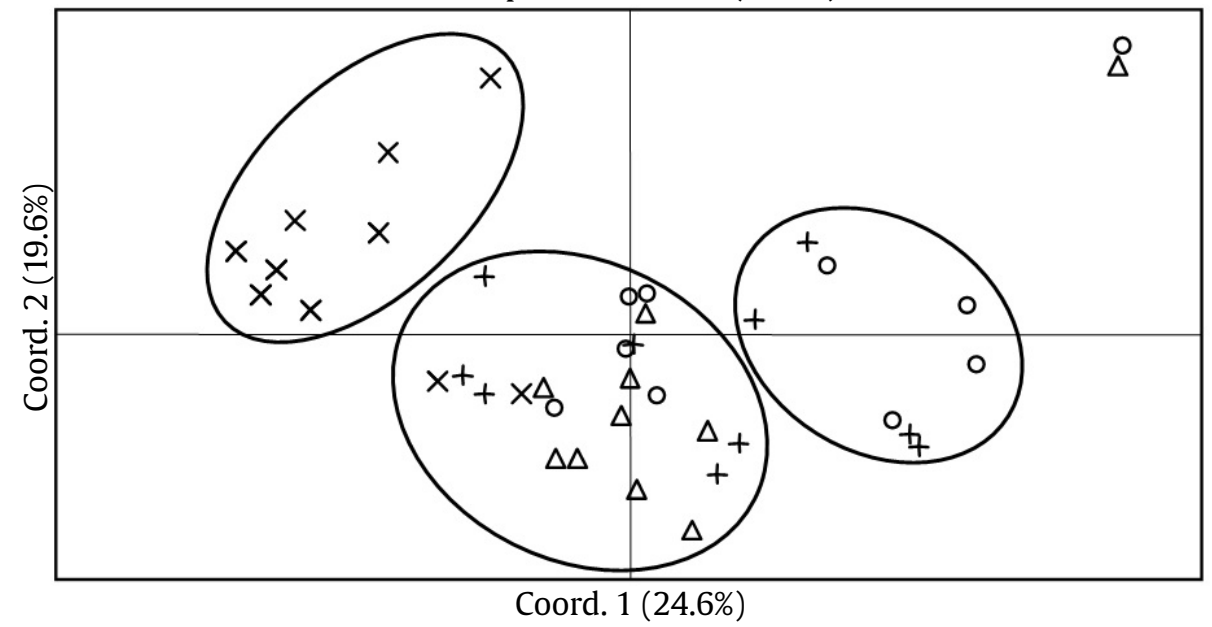

Principal coordinates (1 vs 3 )

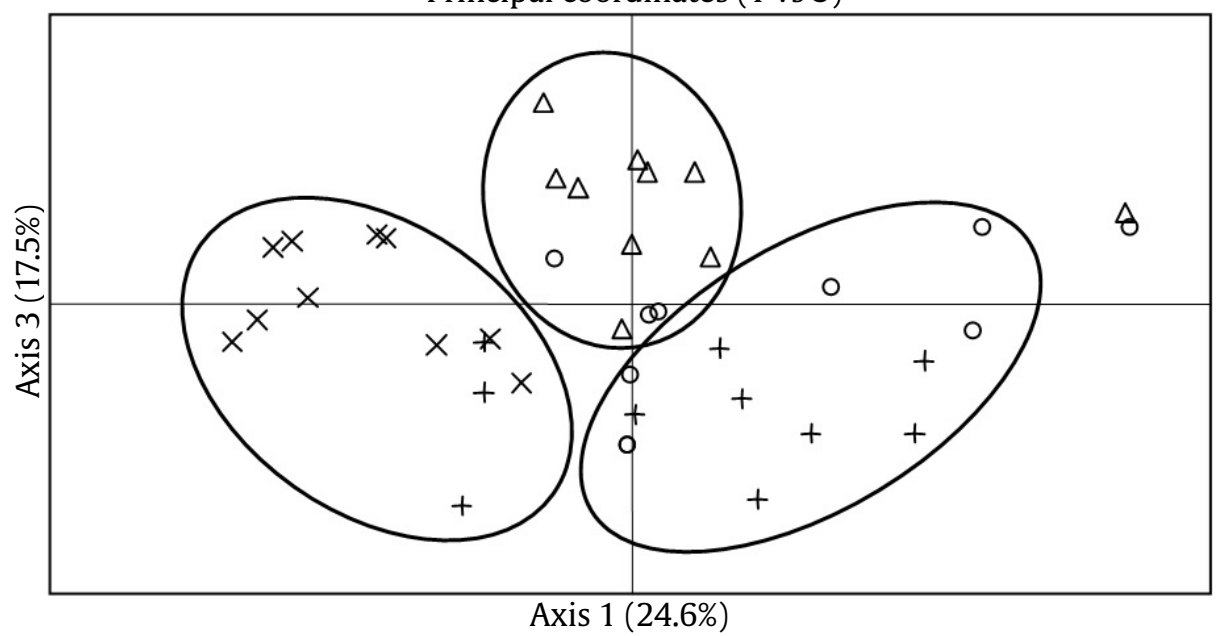

Principal coordinates (2 vs 3 )

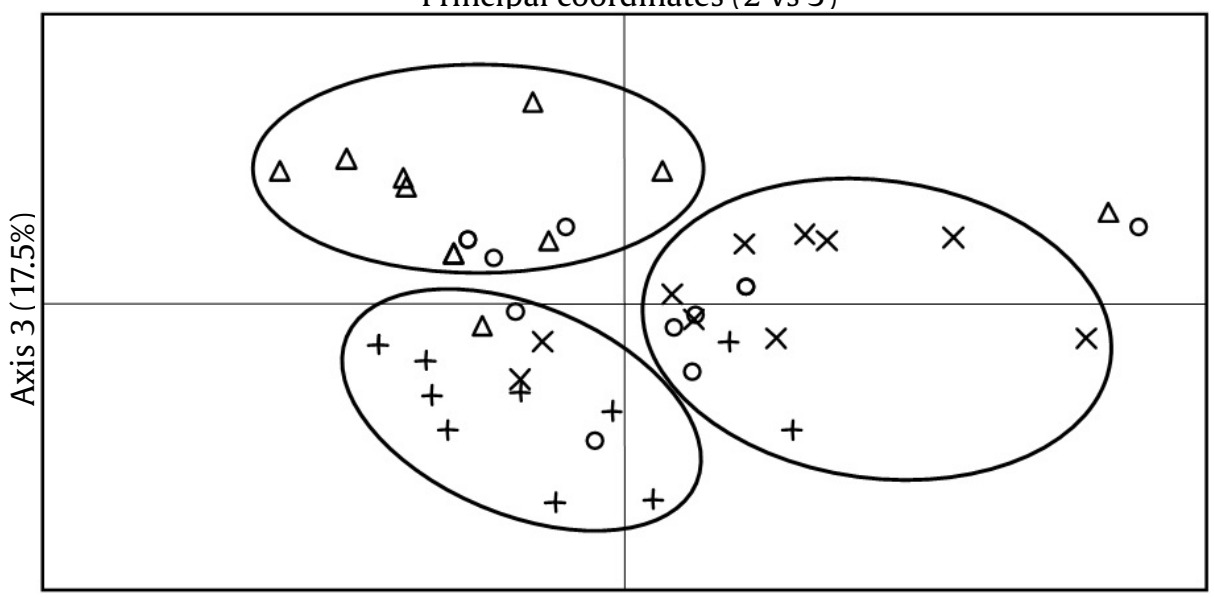

Axis $2(19.6 \%)$

Figure 5. 2D-plots of principal coordinate analysis (PCoA) of four brown planthopper (Nilaparvata lugens Stål) populations artificially selected on differential varieties. Population '+' was maintained on TN1 (no Bph gene), ' $\circ$ 'on Mudgo, ' $\triangle$ ' on ASD7, and population ' $x$ ' was maintained on Rathu Heenathi (Bph3, Bph17) after virulence selection cycles of field populations on Mudgo (Bph1) and ASD7 (bph2) 
high virulence allele frequency (Kobayashi 2016). Therefore, development of a lower level of biotype virulence character from a field population should take more than three generation of adaptation.

Genetic analysis of the four populations with 38 polymorphic SSR primers resulted that almost half of the markers were informative (PIC value $>0.5$ ). However, a similar rate in various genetic parameter values was observed among the developed populations. This could be related to the observed non-varying virulence level among populations. Jing et al. (2012a) observed that SSR genetic diversity of biotypes was positively correlated with host resistance level, i.e. biotypes feeding on resistant rice varieties had higher genetic diversity than those feeding on the susceptible rice variety.

Results of AMOVA indicated a higher genetic variation within (89\%) than among populations. The same result was also observed among BPH biotypes by Bahagiawati and Rijzaani (2005) and Jing et al. (2012a). This trend is a common phenomenon in out-crossing insect species to maintain population's sustainability (Jing et al.2012a).Inbreeding coefficient (Fst) was greater than zero, indicating the presence of significant genetic differentiation among populations. However, the pairwise Fst values were less than 0.15, which according to Frankham et al. (2002) indicates genetic proximity among population. Further analysis with PCoA confirmed the presence of partial genetic differentiation among populations. More than 6 individuals per of population T (plot of axis 1 vs 3 ), A (plot of 1 vs 2 and 2 vs 3 ), and R (plot of axis 1 vs 2 and 1 vs 3 ) clustered according to their group. This partial clustering according to the respective host indicates the presence of a level of genetic adaptation on their hosts.

Based on the virulence characteristics and PCoA clustering, population $\mathrm{R}$ can be used as the resistance screening agent of rice lines to replace a field population. More selection cycles and adaptation on the respective hosts must be continued on population T, M and A to develop biotype 1, 2 and 3, respectively. The time required for shifting a biotype into another can be 5 (Nemoto and Yokoo 2002) to 33 generations (Jing et al. 2012) of adaptation on a single host. After the desired virulence level for the respective population is achieved, complete genetic separation among the populations can be expected (Jing et al. 2012).

\section{Acknowledgements}

We greatly appreciated the assistance of Mr. M. Saputro and Mr. Riko Harmando for insect rearing. Financial support was provided through DIPA ICABIOGRAD 2016 (project number 1798. 011.001.011).

\section{References}

Baehaki SE, Mejaya IMJ. 2014. Wereng cokelat sebagai hama global bernilai ekonomi tinggi dan strategi pengendaliannya. IPTEK Tan Pangan 9:1-12.

Baehaki SE. 2012. Standar Operasional Prosedur Pengujian Galur dan Varietas Padi terhadap Wereng Batang Coklat (Nilaparvata lugens). Jakarta: Badan Penelitian dan Pengembangan Pertanian.

Baehaki SE, Munawar D. 2008. Identifikasi biotipe wereng coklat di Jawa, Sumatera dan Sulawesi dan reaksi ketahanan kultivar padi. In: Prosiding Seminar Apresiasi Hasil Penelitian Padi Menunjang P2BN. Subang: Balai Besar Penelitian Tanaman Padi. pp. 351-366.

Bahagiawati, Rijzaani H. 2005. Pengelompokan biotipe wereng coklat berdasarkan RAPD-PCR. HAYATI J Biosci 12:1-6.

Botstein D et al. 1980. Construction of a genetic linkage map in man using restriction fragment length polymorphisms. Am J Hum Genet 32:314-331.

Brar DS et al. 2009. Breeding for resistance to planhopper in rice. In: Heong KL, Hardy B. (Eds.). Planthoppers New Threats to the Sustainability of Intensive Rice Production Systems in Asia. Los Banõs: IRRI. pp. 401-428.

Chaerani et al. 2016. Virulence of brown planthopper and development of core collection of the pest.JPen Pert Tan Pangan 35:109-117.

Claridge MF et al. 1984. The significance of morphometric and fecundity differences between the 'biotypes' of the brown planthopper, Nilaparvata lugens. Ent Exp Appl 36:104-114.

Claridge MF et al. 1985. Variation in courtship signals and hybridization between geographically definable populations of the rice brown planthopper, Nilaparvata lugens (Stål). Biol J Linn Soc 24:35-49.

Claridge MF, Hollander JD. 1980. The "biotypes" of the rice brown planthopper, Nilaparvata lugens. Entomologia Exp et Appl 27:23-30.

Cheng X et al. 2013. Towards understanding of molecular interactions between rice and the brown planthopper. Mol Plant 6:621-634.

Frankham R et al. 2002. Introduction to Conservation Genetics. Cambridge: Cambridge University Press.

Jairin J et al. 2013. A simple sequence repeat and singlenucleotide polymorphism-based genetic linkage map of the brown planthopper, Nilaparvata lugens. DNA Res 20:17-30.

Jing S et al. 2012a. Development and use of EST-SSR markers for assessing genetic diversity in the brown planthopper (Nilaparvata lugens Stål). Bul Entomol Res 102:113-122.

Jing $S$ et al. 2012b. Isolation and characterization of microsatellite markers in brown planthopper. Int $J$ Mol Sci 13:9527-9533.

Jing $S$ et al. 2014. Genome-wide mapping of virulence in brown planthopper identifies loci that break down host plant resistance. PLOS ONE 9:6. 
Khan ZR, Saxena RC. 1990. Purification of biotype I population of brown planthopper Nilaparvata lugens (Homoptera: Delphacidae). Int J Trop Insect Sci 11:55-62.

Kobayashi T. 2016. Evolving ideas about genetics underlying insect virulence to plant resistance in rice-brown planthopper interactions. J Insect Physiol 84:32-39.

Kumari S et al. 2010. Screening of IR503 Rathu Heenati F7RILs and identification of SSR markers linked to brown planthopper (Nilaparvata lugens Stål) resistance in Rice (Oryza sativa L.). Mol Biotech 46:63-71.

Liu K, Muse SV. 2005. Power marker: an integrated analysis environment for genetic marker analysis. Bioinformatics 21:2128-2129.

Liu YD, Hou ML. 2009. Development of EST-SSRs in the brown planthopper Nilaparvata lugens. Mol Ecol Res 9:1375-1429.

Latif MA et al. 2012. Genetic dissection of sympatric populations of brown planthopper, Nilaparvata lugens (Stal), using DALP-PCR molecular markers. Sci World J 2012:1-11.

Luo Z et al. 2019. Genetic diversity and population structure of a Camelina sativa spring panel. Frontiers in Plant Sci 10:184. DOI:10.3389/fpls.2019.00184

Manzila I et al. 2002. Pemurnian biotipe wereng coklat di laboratorium. In: Prosiding Seminar Hasil Penelitian Rintisan dan Bioteknologi Tanaman. Bogor: Balitbio. pp. 289-300.

Nemoto H, Yokoo M. 2002. Experimental selection of a brown population on mixtures of resistant rice lines. Breeding Sci 44:133-136.

Pathak PK, Heinrichs EA. 1982. Selection of biotype populations 2 and 3 of Nilaparvata lugens by exposure to resistant rice varieties. Env Entomol 11:85-90.

Pathak MD, Khan ZR. 1994. Insect Pests of Rice. Manila: IRRI.
Pathak PK et al. 1982. Parafilm sachet for measuring honeydew excretion by Nilaparvata lugens. J Econ Entomol 75:194195.

Peakall PE, Smouse R. 2012. GenAlEx 6.5: genetic analysis in Excel. Population genetic software for teaching and research-an update. Bioinformatics 28:2537.

Sasmita Petal. 2019. Deskripsi Varietas Unggul Padi. Sukamandi: Badan Penelitian dan Pengembangan Pertanian.

Shufran KA, Whalon ME. 1995. Genetic analysis of brown planthopper biotypes using random amplified polymorphic DNA-polymerase chain reaction (PCRRAPD). Insect Sci Appl 16:27-33.

Sun L et al. 2005. Mapping of a major resistance gene to the brown planthopper in the rice cultivar Rathu Heenati. Breeding Sci 55:391-396.

Sun JT et al. 2011. Mining and characterization of sequence tagged microsatellites from the brown planthopper Nilaparvata lugens Stål. J Insect Sci 11:134.

Tanaka K. 1999. Quantitative genetic analysis of biotypes of the brown planthopper Nilaparvata lugens: heritability of virulence to resistant rice varieties. Entomologia Exp et Appl 90:279-287.

Wenger JA, Michel AP. 2013. Implementing an evolutionary framework for understanding genetic relationships of phenotypically defined insect biotypes in the invasive soybean aphid (Aphis glycines). Evol Appl 6:1041-1053.

$\mathrm{Xu} Y$ et al.2016. Genetic diversity and population structure of Pinus yunnanensis by simple sequence repeat markers. Forest Sci 62:38-47.

Yang $\mathrm{H}$ et al. 2016. Assessing the genetic diversity and genealogical reconstruction of cypress (Cupressus funebris Endl.) breeding parents using SSR markers. Forests 7:160. 